\title{
HTLV in the Americas: challenges and perspectives
}

\author{
Anna Bárbara F. Carneiro-Proietti, ${ }^{1}$ Bernadette C. Catalan-Soares, ${ }^{1}$ \\ Carlos M. Castro-Costa, ${ }^{2}$ Edward L. Murphy, ${ }^{3}$ Ester C. Sabino, ${ }^{4}$ \\ Michie Hisada, ${ }^{5}$ Bernardo Galvão-Castro, ${ }^{6,7}$ Luiz C. J. Alcantara, ${ }^{6}$ \\ Carlo Remondegui, ${ }^{8}$ Kristien Verdonck, ${ }^{9}$ and Fernando A. Proietti ${ }^{10}$
}

Suggested citation Carneiro-Proietti ABF, Catalan-Soares BC, Castro-Costa CM, Murphy EL, Sabino EC, Hisada M, Galvão-Castro B, Alcantara LCJ, Remondegui C, Verdonck K, Proietti FA. HTLV in the Americas: challenges and perspectives. Rev Panam Salud Publica. 2006:19(1):44-53.

ABSTRACT The first description of the human T-lymphotropic virus type 1 (HTLV-1) was made in 1980, followed closely by the discovery of HTLV-2, in 1982. Since then, the main characteristics of these viruses, commonly referred to as HTLV-1/2, have been thoroughly studied. Central and South America and the Caribbean are areas of high prevalence of HTLV-1 and HTVL-2 and have clusters of infected people. The major modes of transmission have been through sexual contact, blood, and mother to child via breast-feeding. HTLV-1 is associated with adult T-cell leukemia/lymphoma (ATL), HTLV-associated myelopathy/tropical spastic paraparesis (HAM/ TSP), and HTLV-associated uveitis as well as infectious dermatitis of children. More clarification is needed in the possible role of HTLV in rheumatologic, psychiatric, and infectious diseases. Since cures for ATL and HAM/TSP are lacking and no vaccine is available to prevent HTLV-1 and HTLV-2 transmission, these illnesses impose enormous social and financial costs on infected individuals, their families, and health care systems. For this reason, public health interventions aimed at counseling and educating high-risk individuals and populations are of vital importance. In the Americas this is especially important in the areas of high prevalence.

Key words Human T-lymphotropic virus 1, human T-lymphotropic virus 2, Retroviridae, RNA tumor viruses, blood donors, preventive medicine, Americas.

1 Fundação Hemominas, Belo Horizonte, Minas Gerais, Brazil. Send correspondence to: Anna Bárbara F. Carneiro-Proietti, Rua Grão Pará, 882 Belo Horizonte, MG, Brazil 30.150-341; e-mail: presid@ hemominas.mg.gov.br or annaproietti@gmail. com; telephone: 5531-32807490; fax: 5531-32849579.

2 Universidade Federal do Ceará, Fortaleza, Ceará, Brazil.

3 University of California, San Francisco, San Francisco, California, United States of America.

4 Fundação Pró-Sangue/Hemocentro de São Paulo, São Paulo, São Paulo, Brasil

National Institutes of Health, National Cancer Institute, Division of Cancer Epidemiology and Genetics, Viral Epidemiology Branch, Bethesda, Maryland, United States of America.

6 Fundação Oswaldo Cruz, Centro de Pesquisas Gonçalo Moniz, Laboratório Avançado de Saúde Pública, Salvador, Bahia, Brazil.
The human T-cell leukemia virus type

1 (HTLV-1) retrovirus was first de-

\footnotetext{
Fundação Bahiana de Desenvolvimento das Ciências, Escola Bahiana de Medicina e Saúde Pública, Salvador, Bahia, Brazil.

8 Hospital San Roque, Servicio de Infectología \& Medicina Tropical, San Salvador de Jujuy, Jujuy, Argentina.

9 Universidad Peruana Cayetano Heredia, Institute of Tropical Medicine Alexander Von Humboldt, Lima, Lima, Peru.

10 Universidade Federal de Minas Gerais, Departamento de Medicina Preventiva e Social, Belo Horizonte, Minas Gerais, Brazil.
}

scribed in 1980 by Poiesz et al (1). Further research in the United States and Japan established for the first time the link between a retrovirus and a human malignancy, adult T-cell leukemia/lymphoma (ATL) (2). HTLV-2 was isolated in 1982 from a hairy cell leukemia cell line, but was later found not to be associated with this variant of leukemia $(3,4)$.

Over the last 25 years the geographical distribution of the HTLV viruses has been identified. The areas of the world with the highest prevalence 
rates for HTLV-1 and HTLV-2 include southwestern Japan, several subSaharan African countries, Central and South America, and localized areas of Iran and Melanesia. In the Americas, higher prevalence rates are found in some countries in the Caribbean, such as Jamaica and Trinidad and Tobago. Somewhat lower seroprevalence rates are found in several countries in South America, including Brazil and Colombia. The major modes of transmission are through sexual contact, blood, and mother to child via breast-feeding (4).

HTLV-3 and HTLV-4 were recently detected in samples from individuals in central Africa, but the association of these two viruses with human disease, as well as their geographical distribution, still need clarification $(5,6)$.

\section{HTLV-ASSOCIATED DISEASES AND THEIR TREATMENT}

Although the exact number of individuals who are seropositive for HTLV-1 and/or HTLV-2 is not known, it is estimated that about 15 to 20 millions persons, mostly HTLV-1-seropositive, are infected worldwide (7). The infections are associated with subclinical immune suppression and resulting opportunistic infections. Even though different syndromes may be implicated with HTLV infection, two main diseases account for the more prominent clinical expressions: adult T-cell leukemia/lymphoma (ATL) and HTLV-1-associated myelopathy/ tropical spastic paraparesis (HAM/ TSP). Although these diseases have low incidence, they are usually severe, producing progressive incapacitation or death. HTLV-associated uveitis and infectious dermatitis are also associated with HTLV-1 (4).

\section{ADULT T-CELL LEUKEMIA/ LYMPHOMA}

ATL is an aggressive lymphoproliferative malignancy linked with short survival in its acute form, and it has an incidence of about $5 \%$ in persons infected with HTLV. It occurs predomi- nantly in adults and affects both men and women with equal frequency. Clinically, it is divided into four subtypes: acute, lymphomatous, chronic, and smoldering. In the most aggressive forms (acute and lymphomatous), half of the patients show weakness; skin, bone, and multiple visceral lesions; pulmonary infiltrates; hypercalcemia; hepatomegaly; splenomegaly; and lymphadenopathy. In the lymphomatous form, superficial or deep lymph node chains are involved. In the smoldering or chronic form, the symptoms are nonspecific, there is no tumor mass involvement, and cutaneous expression is predominant, with papulae, plaques, tumor, or erythroderma of long evolution. Strongyloidiasis is frequently associated with all forms. The pathogenetic mechanisms involved are incompletely understood, but viral Tax protein probably plays a central role (8).

Despite advances in support and development of novel treatment agents, the prognosis for patients with ATL remains poor. The variety of therapeutic approaches tested over the past two decades is immense. Conventional treatment regimens for patients with acute or chronic forms, including conventional chemotherapy and intravenous anti-Tac monoclonal antibody infusion, have not yielded durable and complete remissions. However, since 1995 there have been promising studies combining zidovudine with interferon-alpha, achieving partial or complete responses (9-10).

Allogeneic stem cell transplantation, preceded by intensive chemotherapy with granulocyte colony stimulating factor (G-CSF) support, holds the potential for cure (11). Reduced preparation (conditioning) before transplantation has a possible graft-versusATL effect, and anti-HTLV-1 activity has also been found to be associated with the reduced conditioning procedure (11).

Emerging novel approaches include administering histone deacetylation inhibitors, monoclonal antibodies, and proteasome inhibitors. Comparison between different therapeutic approaches is complicated by the clinical spectrum of ATL. Due to the lack of randomized, controlled trials, there is no clear evidence to support the value of any particular treatment approach over others (11). We should also consider the high cost of these new treatments, which poses a challenge to developing countries already burdened with multiple endemic conditions.

\section{HTLV-1-ASSOCIATED MYELOPATHY/TROPICAL SPASTIC PARAPARESIS}

HAM/TSP is an insidious inflammatory chronic myelopathy of adult patients (average 40 years old), with females predominating. It is found in tropical, developing areas (Africa, the Caribbean, and South America) and temperate zones (Japan), with prevalences ranging from $0.2 \%$ to $5 \%$ among HTLV-1 carriers.

HAM/TSP is clinically characterized by spastic paraparesis and gait disturbance, frequently associated with bladder and sensory dysfunction. Pyramidal signs exist not only in the lower limbs but also in some cases in the upper limbs. In the natural history of the disease, after a period of years or decades, some patients need to use a wheelchair, and about 30\% become bedridden and may die of intercurrent infections. Many patients are less incapacitated and may walk with support for years. Magnetic resonance imaging may evidence thoracic cord atrophy. HAM/TSP is characterized by lymphocytic infiltration of the central nervous system, and immunopathogenic mechanisms are involved in the origin of these lesions $(12,13)$. Guidelines have recently been published in Brazil with the aim of informing health professionals about and guiding them in the prevention, diagnosis, and treatment of these clinical conditions (14).

Besides the symptoms of myelopathy, less frequently seen signs of nervous system dysfunction include peripheral neuropathy, dysautonomia, motor neuron-like syndrome, cerebellar ataxia, myopathy, and cognitive dysfunction. Other non-neurological syndromes have also been described 
as being associated with HTLV-1 infection, including uveitis, arthropathy, Sjögren's syndrome, lymphocytic pneumonitis, infectious dermatitis, and other dermatoses.

As to HTLV-2-associated clinical conditions, there are rare reports of possible HAM/TSP-like syndromes with ataxic symptoms, and descriptions of sensory polyneuropathies and inflammatory myopathies, with the latter still lacking stronger evidence of association with HTLV-2 infection. (15).

Up to now, no treatment for HAM/ TSP has proven to be effective consistently and in the long term. The current gold standard encompasses multiple approaches: anti-inflammatory, antiretroviral, and antispastic drugs; infection prophylaxis in patients under long-term immune suppressive therapy (including isoniazid for tuberculosis), antibiotics for bladder infections, prevention and treatment of bedsores, kinesiotherapy and rehabilitation.

Based on the hypotheses that HAM/ TSP pathogenesis involves an autoimmune reaction or that the damage is a consequence of cytotoxic Tlymphocyte (CTL) activity and cytokine release, immunotherapy aimed at inhibiting CTL activation has been tried. Used frequently, steroids have been shown to bring about clinical improvement. However, short duration of the effect and even progression of the disease under treatment are common $(16,17)$. In addition, steroids can activate or aggravate parasitic and other infectious diseases (18). As treatment dose and duration are not yet defined in the literature, minimal doses that improve a patient's quality of life should be prescribed. The spasticity of the lower limbs may also improve with central antispastic drugs, in association with kinesiotherapy.

Interferon-alpha has been proposed as a therapeutic option for HAM/TSP because of its immune modulating and antiviral activity. There have been clinical trials, but the follow-up period was short (19). Nucleoside analogue antiretrovirals, such as lamivudine and zidovudine, have also been tried, but mostly in small studies. One double- blind placebo-controlled randomized trial of 16 cases did not show any benefit from this treatment.

Concomitant pathologies and conditions found in HAM/TSP patients, such as malnutrition, anemia, tuberculosis, HIV infection, parasitosis, bladder infections, and diabetes, are frequent, and they should also be treated.

In patients with chronic steroid use, additional treatment for adverse effects may become necessary. Self-help resources and patient support groups are both important.

\section{THE EPIDEMIOLOGY OF HTLV INFECTION IN THE AMERICAS}

\section{North America}

There are no population-based studies of HTLV-1 and -2 prevalences in North America. Published reports based on serologic screening of volunteer blood donors are likely to underestimate population prevalence by a factor of two or three. Nevertheless, these studies indicate that confirmed HTLV prevalence is quite low, on the order of 3 cases of infection per 10000 blood donors, with 1 per 10000 for HTLV-1 and 2 per 10000 for HTLV-2
(20). However, there is a classical pattern of age and sex dependence of HTLV-1 seroprevalence among blood donors, with prevalence higher in females and increasing steadily with age (Figure 1). This is similar to patterns seen in endemic areas of southern Japan and the Caribbean. This suggests that HTLV-1 infection in North America is an older phenomenon due to the immigration from HTLV-1-endemic areas, with subsequent maintenance in the population due to mother-to-child and sexual transmission. HTLV-2 seroprevalence among North American blood donors also shows a female excess, but with peak prevalence among those 30 to 49 years of age, and lower prevalence in younger and older age groups (Figure 2). Investigators have attributed this age and sex distribution to an age cohort effect resulting from an epidemic of HTLV-2 infection during the 1960s and 1970s that was caused by a contemporaneous epidemic of injection drug use and secondary sexual transmission.

Supporting evidence for this hypothesis is the high prevalence of HTLV-2 among most populations of injection drug users (IDUs) in North America. An HTLV-2 seroprevalence of almost

FIGURE 1. Age- and sex-specific seroprevalence of HTLV-1 among blood donors in the United States ${ }^{a}$

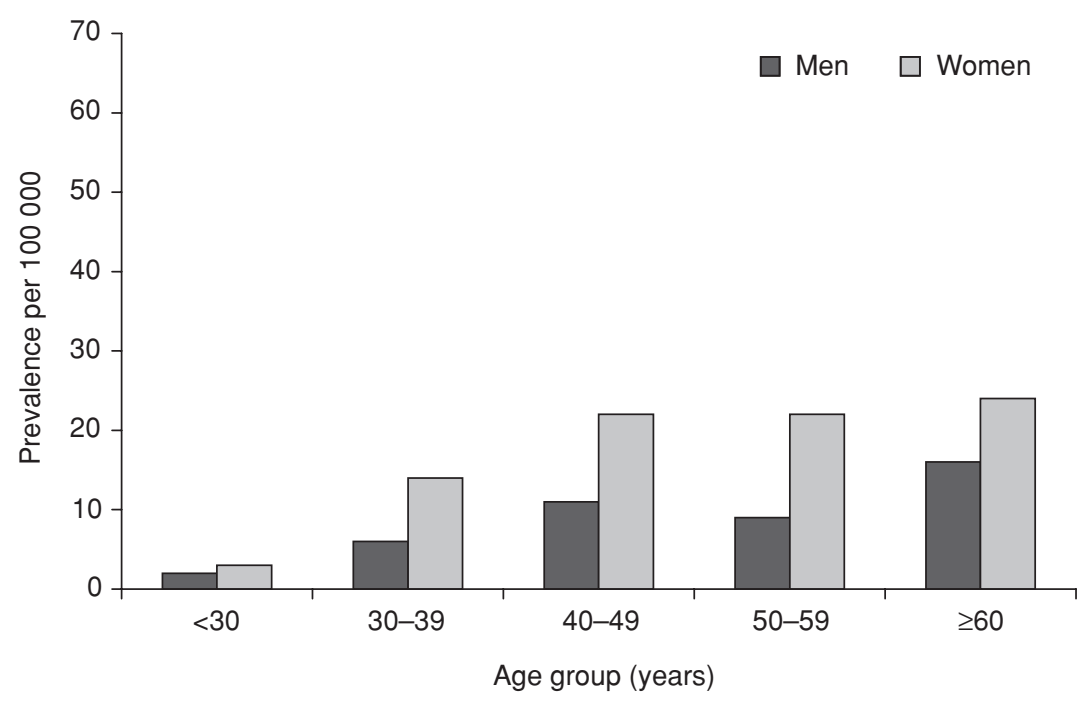

a Modified from Murphy et al. (20). 
FIGURE 2. Age- and sex-specific seroprevalence of HTLV-2 among blood donors in the United States ${ }^{\mathrm{a}}$

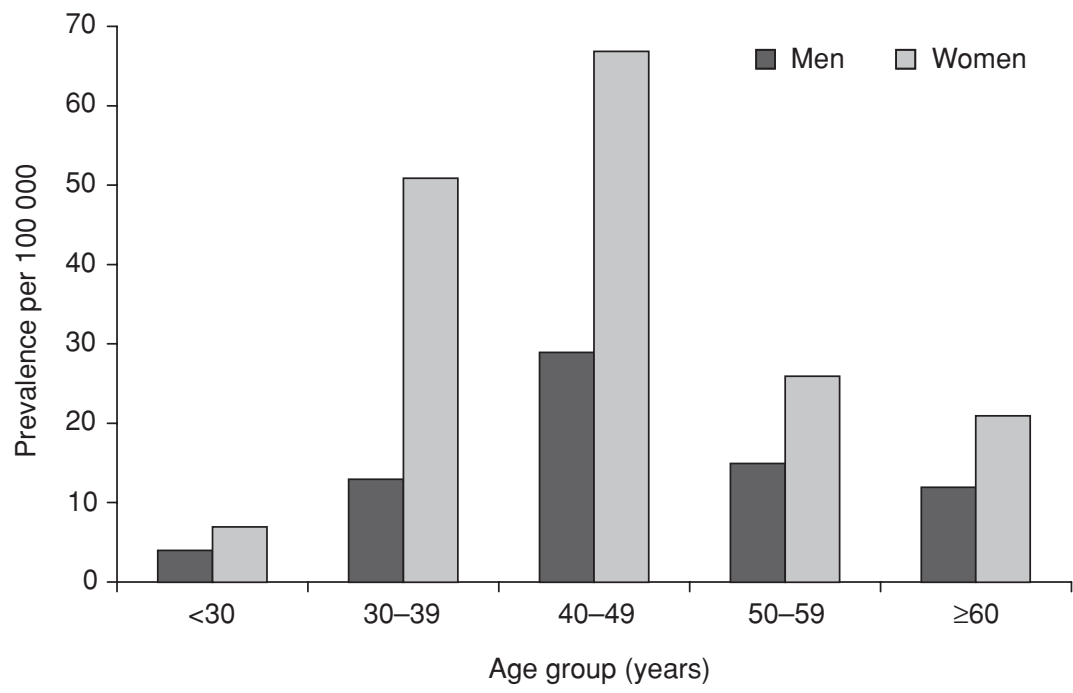

${ }^{\text {a }}$ Modified from Murphy et al. (20).

$25 \%$ was first described among IDUs in the city of New Orleans, Louisiana, and New York City areas (21); rates of $10 \%$ to $20 \%$ have subsequently been found among IDUs on the West Coast of the United States (22). In contrast, IDUs in the northeastern and southeastern United States tend to have a mixture of HTLV-1 and HTLV-2 infections, most likely due to an admixture of immigrants from HTLV-1-endemic areas of the Caribbean. Risk factors for HTLV-2 infection included female gender, black or Hispanic heritage, and longer duration of heroin injection among IDUs (23). In contrast, HIV prevalence was stable in all age groups and was associated with cocaine, not heroin, injection. Along with Figure 1 and Figure 2, these data suggest that sexual infection of female sexual partners of IDUs produces a large reservoir of HTLV-2 infection, and this route is the most likely one for dissemination of the virus to the general population.

In North America, there are few large well-sampled studies of HTLV infection among Native Americans. Several smaller studies have reported seroprevalences of HTLV-2 infection, generally from $1 \%$ to $5 \%$, among the following tribes: the Navajo and
Pueblo of the state of New Mexico (United States), the Seminole of the state of Florida (United States), the Nuu-chah-nulth of the province of British Columbia (Canada), and the Maya of Mexico (24). Some of these studies were limited by the use of earlier serologic screening and confirmatory assays, or the lack of precise HTLV typing or molecular characterization of the virus. The small sample size in most of the studies also limited the determination of age- and sexspecific seroprevalence. Further, we are unaware of any published reports examining mother-to-child or sexual transmission within Native American populations in North America. In the southwestern United States, one study did find a high HTLV-2 prevalence among Native Americans with tuzberculosis infection at Indian Health Service clinics, suggesting that HTLV-2 may be related to the high prevalence of tuberculosis in this population (25).

\section{Epidemiology of HTLV infection in Central America and the Caribbean}

The seroepidemiology of HTLV-1 and HTLV-2 infection has been exten- sively studied in Central America and the Caribbean. The overall seroprevalence of infection from populationbased surveys ranges between $1 \%$ and $10 \%$ in most studies (Table 1) (26-42). Age-dependent increase and female predominance in seroprevalence, as well as the presence of familial clustering, are similar to those observed in other endemic areas. The association of HTLV-1 infection with ATL, HAM/TSP, uveitis, and infectious dermatitis has been well established, as is the association of HTLV-2 with HAM/TSP-like neurological disease (43-45). Thus, the seroprevalence of HTLV-1 among patients with hematological malignancies or with neurologic, ocular, or skin disorders is higher. HTLV infections pose a significant burden of illness. For example, in the Caribbean, where cohort studies of HTLV-1-infected persons have been conducted, the incidence of ATL and HAM/TSP has each been estimated to be 20 per 100000 population per year (46).

\section{Epidemiology of HTLV infection in South America}

Phylogenetic studies suggest that HTLV-1 arrived in South America through multiple, rather recent introductions, probably during the several hundred years of the African slave trade that began in the 16th century, and through Japanese immigration at the beginning of the 20th century. Whether HTLV-1 was already present in South America before the arrival of the Spaniards in the 15th century is still unclear (47).

All 13 South American countries have reported the presence of HTLV-1, but the prevalence varies greatly (from less than $0.1 \%$ to over 5\%) among and within the countries and population groups. Among Amerindian populations, HTLV-1 is present in northern Argentina (Toba tribe), central and southern Bolivia (Quechua and Aymara Indians), northern and southern Chile (Atacameño, Aymara, Mapuche, and Huilliche Indians), southern Colombia 
TABLE 1. Reported seroprevalence (\%) of HTLV-1/2 infection in Mexico, Central America, and the Caribbean

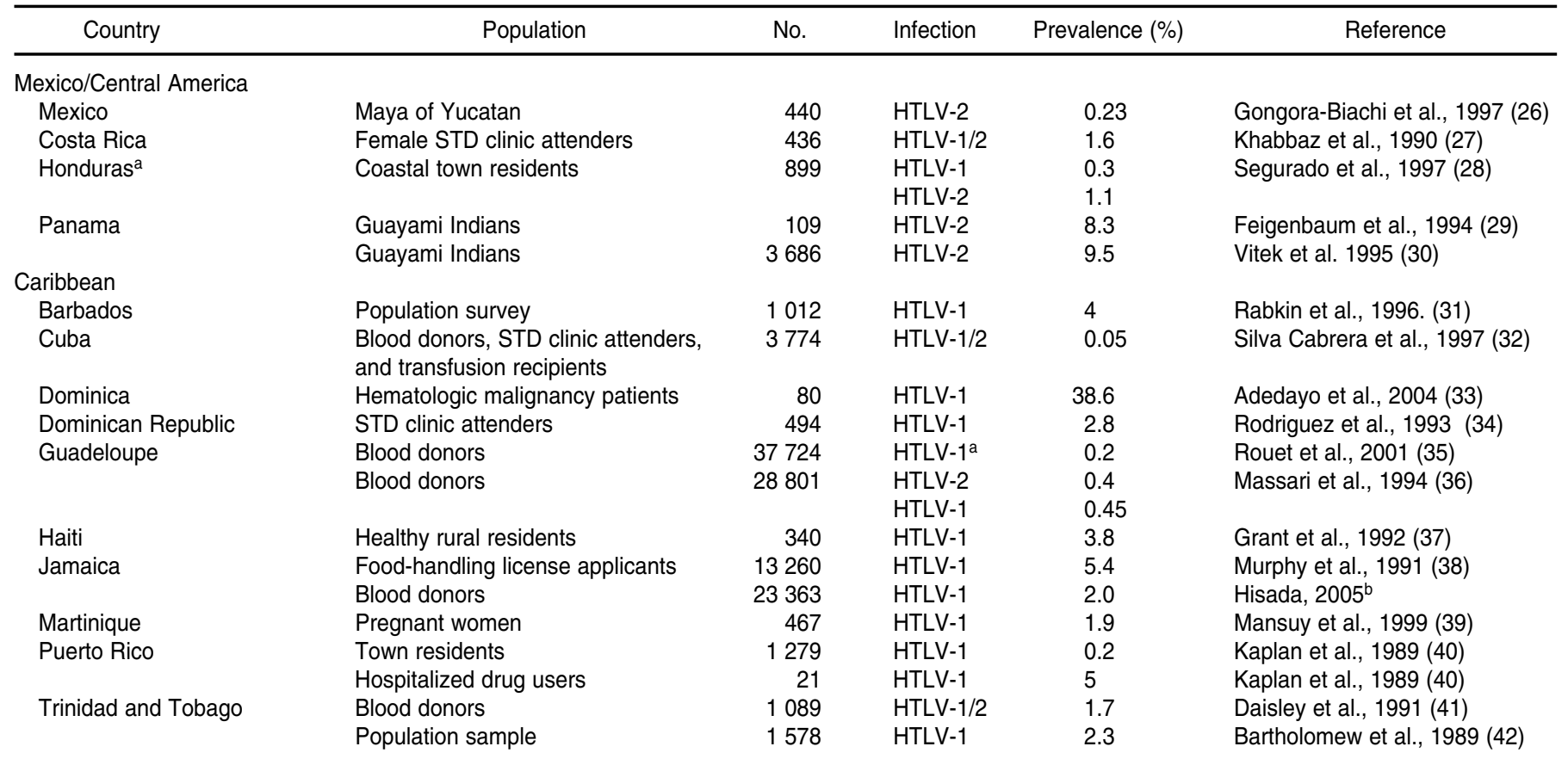

a Tested for HTLV-1 and HTLV-2.

${ }^{b}$ Hisada M, et al. (unpublished data).

(tribes of the Chibchan language family), Paraguay (Sanapaná), and southeastern Peru (Quechua and Aymara). HTLV-1 is also found in regions with an important African-American population such as the state of Bahia in Brazil, French Guiana, Guyana, Suriname, and the Pacific coast of Colombia (Tumaco City) and of Peru (Chincha province). Infection with HTLV-1 is also reported among Japanese immigrants to Bolivia, Brazil, and Peru and among their descendants (47-49).

The highest proportions of infection among the general population ( $1 \%$ to $5 \%$ ) have been described in Brazil, Colombia, and Peru. In general, HTLV-1 prevalence increases with age and is higher in women. In specific risk groups, such as commercial sex workers, intravenous drug users, and HIVinfected persons, up to $20 \%$ of individuals may be infected with HTLV-1. In contrast, HTLV-1 appears to be uncommon in central and southern Argentina and in Venezuela (47-49).
The geographical distribution of HTLV-2 in South America differs from that of HTLV-1. Based on phylogenetic analyses (see the following section on molecular epidemiology) and on the presence of HTLV-2 in isolated Amerindian communities, it is now thought that HTLV-2 has been present in South America since pre-Columbian times. However, later introductions may have occurred as well, as HTLV-2 is present in regions in Africa from where slaves were brought to South America (47-50).

In contrast to HTLV-1, HTLV-2 is found mostly in the South American lowlands, from the Atlantic coast of Colombia to the south of Chile. There are reports from Argentina (Toba and Mapuche populations), Brazil (Amazon region: Kayapó and Krahô), Chile, Colombia (Wayuu, Guahibo, and Tunebo), Paraguay (Nivaclé and Lengua), and Venezuela (Guahibo, Pumé, and Barí). HTLV-2 is uncommon in French Guiana, Guyana, Peru, and Suriname (47-49).

\section{THE MOLECULAR EPIDEMIOLOGY OF HTLV-1 AND -2 SUBTYPES IN THE AMERICAS}

HTLV-1 and HTLV-2 originated independently and may have arisen from distinct lineages of simian viruses (STLV-1 and -2, respectively). Seven genetic subtypes have been proposed in the phylogenetic classification of HTLV-1: a or Cosmopolitan, distributed throughout the world; $b$ or Central African; c or Melanesian, a divergent strain isolated in Australia and Papua New Guinea; d, from Central African Republic pygmies and from two patients in Cameroon and Gabon; e, identified in a sample from an Efe pygmy from the Democratic Republic of Congo; and $\mathrm{f}$, from one individual from Gabon) (51). HTLV-1 subtype $g$ was recently described, isolated from populations in southern Cameroon (7). The Cosmopolitan subtype is divided into five subgroups, according to the geographical distribution: Transcontinental (A), Japanese (B), West 
African (C), North African (D), and Black Peruvian (E).

Only the HTLV-1 strains of the Cosmopolitan subtype (HTLV-1 genetic subtype a) have been isolated from different endemic and nonendemic areas throughout the Americas, and their limited sequence variation has hindered comparative molecular studies. These strains must have been carried out of Africa by their human hosts either during the pre-Columbian ancient human migrations out of Africa or possibly during the slave trade between the 16th and 19th centuries (52, 53). Subgroup E of the Cosmopolitan subtype was characterized in Peru, in only two individuals. The Bl1.Peru isolate had a mitochondrial DNA type identical to that of some West African source populations (54). In the Americas, the strains of the West African subgroup $C$ were identified in the Caribbean and in French Guiana, but not in Brazil, despite the fact that most of its inhabitants were brought from Western Africa during the slave trade (55). The relationship between Asian migration to the Americas thousands of years ago and the recent Japanese immigration could explain the presence of the HTLV-1 Cosmopolitan a subtype, Japanese (B) subgroup in the Americas $(56,57)$. This HTLV-1 subtype a subgroup $B$ has been characterized in northern, northeastern, and southeastern Brazil; British Columbia (Canada); Colombia; and Peru (55-57). Previous reports suggested a postColumbian spread of both the Japanese B and Transcontinental A subgroups to the Americas, possibly through separate introductions from different parts of Africa (55-59). The Transcontinental A subgroup has been characterized in both North America (Canada and United States) and South America (Argen-tina, Brazil, Chile, Colombia, French Guiana, and Peru) $(56,57,60)$.

There are three main well-established subtypes of HTLV-2: a, b, and d (60). A molecular variant of subtype a was characterized and named as subtype c, based on the properties of its Tax protein (60-63). In North America, early studies indicated that subtype $b$ was concentrated among Native American populations, whereas a mixture of HTLV-2a and HTLV-2b was generally found among IDUs and their sexual partners (60). A subsequent large study among blood donors with HTLV-2 infection found differences in subtypes a and $\mathrm{b}$ according to race and geographic area (64). These authors suggested that HTLV-2 subtype a0 spread in a moderate epidemic among African-Americans in several geographic areas of the United States during the 1960s and 1970s, whereas HTLV-2 subtypes b4 and b5 spread predominantly among other races, perhaps originating from Native Americans in and around the state of Oklahoma. The Navajo and Pueblo tribes, in the state of New Mexico, are infected with both subtypes (a and b), while only subtype b was isolated in the Seminole tribe of the state of Florida. In the other Amerindian tribes, only HTLV-2 subtype b was found, in the Toba from Argentina, Mapuche from Chile, Wayuu and Guahibo from Colombia, and Guaymi from Panama. While the HTLV-2a and HTLV-2b subtypes were found in Amerindian tribes from the north to the south of the Americas, only HTLV-2c (also called variant HTLV-2a) has been found in the Kayapó, Krahô, Kaxuyama, and Tiriyo tribes of Brazil (62-64). In addition, this same variant was characterized in both IDU and non-IDU urban populations in Brazil $(59,63)$. There is controversy regarding the nomenclature of this variant as either Brazilian variant of the subtype a or of the subtype c, because these isolates have an extended form of the Tax protein like subtype $\mathrm{Bb}$, but form a Brazilian monophyletic cluster in the phylogenetic tree with HTLV-2 subtype a isolates, when the long terminal repeats (LTR) or $e n v$ regions are analyzed. Interestingly, two strains of HTLV-2a were characterized among British Columbia (Canada) Amerindians, one of them having an extended form of Tax and clustering with the other HTLV-2a strains that lack an extended form of Tax, in the LTR region phylogenetic tree (64). Therefore, the presence of subtype a isolates with a long Tax protein, clustering with other subtype a isolates having a short or long Tax protein (the Bra- zilian variant), could not suggest the existence of subtype $c$ based on the length of the Tax protein.

The heterogeneity of HTLV subtype and subgroup distributions shows little evidence of adaptation or natural selection due either to immune selection pressures of the host or to environmental factors. For this reason, HTLV provides an excellent evolutionary model, which may lead to new insights for evaluating the spread and genetic evolution of these important human pathogens.

\section{HTLV BLOOD SCREENING IN TRANSFUSION SERVICES}

The possibility of transmission of HTLV-1 and HTLV-2 through blood products has led public health authorities in many countries throughout the world to institute routine screening procedures for these retroviruses in donated blood. Systematic HTLV screening in blood banks is already mandatory in Brazil, Canada, Peru, the United States, Uruguay, and Jamaica and some other countries in the Caribbean, as well as in endemic regions of Argentina and Venezuela. The high cost of the tests has been the major factor limiting widespread use of HTLV blood screening in the Americas.

One problem faced by all countries that introduced HTLV blood screening was the high rate of false reactivity associated with first-generation commercial HTLV enzyme-linked immunosorbent assay (ELISA) kits. For example, the rate of discarded units subsequent to HTLV screening reached levels of 2.5\% when testing first began in 1991 in Brazil (65). The introduction of secondand third-generation assays in Brazil has decreased this false-reactivity rate to levels similar to that seen now in Europe and the United States.

Confirmatory testing presents another challenge for transfusion services. The Western blot (WB) technique is the only commercially available one in the Americas. Besides being high in cost, WB testing often gives rise to complex reactivity patterns, frequently rendering results inconclusive due to 
the presence of nonspecific bands. Even immunoblotting assays based on recombinant antigens do not resolve a high percentage of reactive samples (66). This makes counseling for ELISAreactive blood donors even more complex, often requiring the collection of a second sample for repetition of ELISA and WB.

An alternative approach to this problem is to change the confirmatory algorithm. Instead of submitting all repeat reactive samples on the primary ELISA to a confirmatory assay, an alternative ELISA is sequentially used. Only samples reactive to both assays are submitted to confirmatory assay. Suggested by Seed et al. (67), this alternative algorithm has resulted in a significant reduction in both the number of confirmatory tests and the proportion of indeterminate results, without impacting sensitivity.

Molecular biological tests, such as detection of HTLV provirus by the polymerase chain reaction (PCR) technique, could also be used for confirmation, although there is no commercially available test, and the sensitivity of the home-made assays may vary.

The identification of two diverse HTLV strains in central Africa may pose another significant challenge for HTLV blood screening $(5,6)$. It is not clear how sensitive the contemporary ELISA assays are for these new variants and how difficult it will be to find adequate antigens to be used as a confirmatory assay.

\section{IMPACT OF HTLV INFECTION IN THE AMERICAS, AND THE CHALLENGE OF ESTABLISHING PREVENTIVE MEASURES}

The majority of HTLV-1-infected individuals remain asymptomatic. Nevertheless, HTLV-1 is an important cause of morbidity and mortality. Both ATL and HAM/TSP may occur in about $1 \%$ to $5 \%$ of infected subjects. Furthermore, HTLV-1-infected individuals are at increased risk of developing inflammatory and infectious diseases, such as alveolitis, Sjögren's syndrome, uveitis, arthropathy, poly- myositis, leprosy, tuberculosis, scabies, infectious dermatitis, and severe forms of strongyloidiasis.

There is less information on health problems associated with HTLV-2 infection. Until recently it was thought that the risk of HTLV-2-associated diseases was negligible. However, a cohort study in the United States has shown that HTLV-2-infected people are at increased risk of developing several inflammatory and infectious diseases, and that they have higher mortality rates than do seronegative persons. Given that finding, the possible impact of HTLV-2 in endemic areas should be reviewed (68).

Since there is no effective treatment for HTLV-1- and HTLV-2-associated diseases, except perhaps for uveitis, the reduction of morbidity and mortality associated with the viruses may have to rely on successful prevention of infection. Beginning in the 1990s, some countries in the Americas initiated the screening of blood supplies. Where this screening has been done, it has reduced the risk of bloodborne transmission of HTLV-1 and HTLV-2 (see the section above on HTLV blood screening).

Ideally, transfusion services should not only remove these blood supplies from circulation but also advise all seropositive persons to defer future donations of blood, plasma, organs, tissue, or sperm. Health professionals should provide education and counseling to all seropositive persons about the significance of HTLV infection and the probability of disease and of transmission to others, and those persons should also be told to not share needles, syringes, or other injection paraphernalia. Educating the broader community about HTLV infections is of paramount importance, in order to minimize the anxiety among those who are positive and to protect them from social stigma and discrimination.

Despite the cost of HTLV-1 and HTLV-2 screening, it is certainly beneficial in preventing new infections in areas with high and medium seroprevalences. It is especially important in curtailing mother-to-child transmission, and thus the production of new generations of HTLV carriers. HTLV screening of pregnant women and discouraging breast-feeding by infected women have been used in Japan to successfully reduce mother-to-child transmission, and will probably reduce the future incidence of ATL. In areas with a high prevalence of HTLV-1 in the general population, such as the Caribbean and South America, this approach is highly desirable. To accomplish this, seropositive women of childbearing age should be fully educated about the risks of infecting their infants by breast-feeding them. These women should be encouraged to refrain from nursing completely, or to limit it to a maximum of three months. Mothers with high HTLV-1 antibody titers and provirus load are most likely to transmit infection to their children, and they should be the primary target for an intervention (69). However, important consideration must be given to the fact that breast milk provides immunity to many life-threatening infections in infancy. For this reason, the benefits of breast-feeding often outweigh the risks associated with the consequences of HTLV-1 and HTLV-2 infection. In summary, screening of pregnant women to reduce transmission of HTLV can be successful only if there are substantial resources allocated to screen and educate mothers, an ample supply of formula, and access to medical care for acute illnesses that are common among bottlefed infants.

Although the rate of sexual transmission of HTLV appears to be low, this transmission route presents the largest challenge of all, due to the difficulties of modifying sexual behaviors. HTLV-1- and HTLV-2-positive persons should be informed of their serostatus, be advised to reduce the number of sexual partners, and be encouraged to practice safe sex and to avoid needle sharing. Partners of seropositive persons should also be screened for HTLV-1 and HTLV-2, among other sexually transmitted infections. Here again, information and early intervention are fundamental. Youth may be an excellent primary target for prevention programs. 
One challenge with HTLV-1 and HTLV-2 infection in Latin America and the Caribbean (LAC) is the possible exacerbation of HIV infection, which is already posing a significant public health problem. Dual infection by HIV and HTLV may also accelerate progression and exacerbate transmission of other infectious diseases, including hepatitis C (70). It is critical for intervention programs to reach out to the poor and the disadvantaged, among whom HIV and HTLV-1 and HTLV-2 are propagating. Given that similar modes of transmission are shared by HTLV and HIV, a simultaneous intervention could be implemented for both infections in settings where there are limited public health resources.

\section{CONCLUSIONS}

Because of the frequency of HTLV-1 and HTLV-2 and the severity of the associated diseases, these infections should be considered a public health concern in the LAC countries, and interventions to reduce their spread should be implemented. Although there are strong agreements on the need for counseling all HTLV-1- and HTLV-2-positive persons, government guidelines are not homogeneously enforced in all the LAC nations. Some recommendations made by experts from the United States Public Health Service and from other countries cannot be put into place without modifications that cater to the needs and priori- ties of the LAC nations, with their limited health care resources. Intervention programs in the LAC countries can be successful only if there is a concerted effort by the respective local governments, blood banks, physicians, health educators, and international organizations with adequate funding.

Acknowledgements: Fernando A. Proietti and Anna Bárbara F. CarneiroProietti are supported by Brazilian agencies Conselho Nacional de Desenvolvimento Científico e Tecnológico (CNPq) and Fundação de Auxílio a Pesquisa do Estado de Minas Gerais (FAPEMIG). We thank Eduardo Gotuzzo and Elsa González for reviewing the manuscript.

\section{REFERENCES}

1. Poiesz BJ, Ruscetti FW, Gazdar AF, Bunn PA, Minna JD, Gallo RC. Detection and isolation of type $\mathrm{C}$ retrovirus particles from fresh and cultured lymphocytes of a patient with cutaneous T-cell lymphoma. Proc Natl Acad Sci U S A. 1980;77(12): 7415-9.

2. Yoshida M, Seiki M, Yamaguchi K, Takatsuki K. Monoclonal integration of human $\mathrm{T}$-cell leukemia provirus in all primary tumors of adult T-cell leukemia suggests causative role of human T-cell leukemia virus in the disease. Proc Natl Acad Sci U S A. 1984;81(8):2534-7.

3. Kalyanaraman VS, Sarngadharan MG, Robert-Guroff $M$. A new subtype of human T-cell leukemia virus (HTLV-II) associated with a T-cell variant of hairy cell leukemia. Science. 1982;218:571-3.

4. Proietti FA, Carneiro-Proietti AB, CatalanSoares BC, Murphy EL. Global epidemiology of HTLV-I infection and associated diseases. Oncogene. 2005;24:6058-68.

5. Calattini S, Chevalier AS, Duprez R, Bassot S, Froment A, Mahieux R, et al. Discovery of a new human T-cell lymphotropic virus (HTLV-3) in Central Africa. Retrovirology. 2005;2:31-4.

6. Wolfe ND, Heneine W, Carr JK, Garcia AD, Shanmugam V, Tamoufe U, et al. Emergence of unique primate $\mathrm{T}$ lymphotropic viruses among central African bushmeat hunters. Proc Natl Acad Sci U S A. 2005;102(22):7994-9.

7. Edlich RF, Arnette JA, Williams FM. Global epidemic of human T-cell lymphotropic virus type-I (HTLV-I). J Emerg Med. 2000;18(1):109-19.

8. Shimoyama M. Diagnostic criteria and classification of clinical subtypes of adult T-cell leukaemia/lymphoma. A report from the Lymphoma Study Group (198487). Br J Haematol. 1991;79(3):428-37.

9. Gill PS, Harrington W Jr, Kaplan MH, Ribeiro RC, Bennett JM, Liebman HA, et al. Treatment of adult T-cell leukemialymphoma with a combination of interferon alfa and zidovudine. N Engl J Med. 1995; 29;332:1744-8.

10. Taylor GP, Matsuoka M. Natural history of adult T-cell leukemia/lymphoma and approaches to therapy. Oncogene. 2005; 24(39):6047-57.

11. Okamura J, Utsunomiya A, Tanosaki R, Naokuni U, Sonoda S, Kannagi M, et al. Allogeneic stem-cell transplantation with reduced conditioning intensity as a novel immunotherapy and antiviral therapy for adult T-cell leukemia/lymphoma. Blood. 2005;105(10):4143-5.

12. De Castro-Costa CM, Carton H, Goubau P, D'Almeida JAC. Brazilian studies on tropical spastic paraparesis: a metaanalysis. Arq Neuropsiquiatr. 1994;52(4): 585-91.

13. De Castro-Costa CM, Dom R, Carton $H$, Santos TJT, Andrada-Serpa MJ. Neuropathology of human and experimental TSP/HAM: a critical review. Acta Neurol Belg. 2002;102:21-9.

14. Brasil, Ministério da Saúde. Guia de manejo clínico do paciente com HTLV. Brasília: Editora MS; 2003.

15. Araújo A, Hall WW. Human Tlymphotropic virus type II and neurological disease. Ann Neurol. 2004;56 (1):10-9.

16. Kira J, Fujihara K, Itoyama Y. Leukoencephalopathy in HTLV-I-associated myelopathy/tropical spastic paraparesis: MRI analysis and a two year follow-up study after corticosteroid therapy. J Neurol Sci. 1991;106:41-9.
17. Nakagawa M, Nakahara $K$, Maruyama $Y$. Therapeutic trials in 200 patients with HTLV-I-associated myelopathy/tropical spastic paraparesis. J Neurovirol. 1996;2: 345-55.

18. Thomas MC, Costello SA. Disseminated strongyloidiasis arising from a single dose of dexamethasone before stereotactic radiosurgery. Int J Clin Pract. 1998;52:520-1.

19. Yamasaki K, Kira J, Koyanagi Y. Longterm, high dose interferon-alpha treatment in HTLV-I-associated myelopathy/ tropical spastic paraparesis: a combined clinical, virological and immunological study. J Neurol Sci. 1997;147:135-44.

20. Murphy E, Watanabe K, Nass C, Ownby H, Williams A, Nemo G. Evidence among blood donors for a 30-year-old epidemic of human T lymphotropic virus type II infection in the United States. J Infect Dis. 1999;180(6):1777-83.

21. Lee HH, Weiss S, Brown L, Mildvan D, Shorty V, Saravolatz L, et al. Patterns of HIV-1 and HTLV-I/II in intravenous drug abusers from the middle Atlantic and central regions of the USA. J Infect Dis. 1990;162:347-52.

22. Khabbaz R, Oronato I, Cannon R, Hartley $T$, Roberts B, Hosein B, et al. Seroprevalence of HTLV-1 and HTLV-2 among intravenous drug users and persons in clinics for sexually transmitted diseases. $\mathrm{N}$ Engl J Med. 1992;326(6):375-80.

23. Feigal E, Murphy E, Vranizan K, Bachetti $P$, Chaisson R, Drummond J, et al. Human $\mathrm{T}$ cell lymphotropic virus type I and II in intravenous drug users in San Francisco: risk factors associated with seropositivity. J Infect Dis. 1991;164:36-42.

24. Roucoux DF, Murphy EL. The epidemiology and disease outcomes of human T- 
lymphotropic virus type II. AIDS Rev. 2004;6(3):144-54.

25. Hjelle B, Khabbaz R, Conway G, North C, Green D, Kaplan JE. Prevalence of human T cell lymphotropic virus type II in American Indian populations of the southwestern United States. Am J Trop Med Hyg. 1994;51(1):11-5.

26. Gongora-Bianchi RA, Lal RB, Rudolph DL, Castro-Sansores C, GonzalezMartinez P, Pavia-Ruz N. Low prevalence of HTLV-II in Mayan Indians in the Yucatan Peninsula, Mexico. Arch Med Res. 1997;28:555-8.

27. Khabbaz RF, Hartley TM, Oberle MW, Rosero-Bixby L. Seroprevalence of human T-lymphotropic virus type I (HTLV-I) in Cost Rica. AIDS Res Hum Retroviruses. 1990;6:959-60.

28. Segurado A, Granade T, Parekh B, Nunez CA, Meza R, Amador L, et al. Presence of HTLV-I and HTLV-II infection in Honduras. J Acquir Immune Defic Syndr Hum Retrovirol. 1997;16:308.

29. Feigenbaum F, Fang C, Sandler SG. Human T-lymphotropic virus type II in Panamanian Guaymi Indians. Transfusion. 1994;34:158-61.

30. Vitek CR, Gracia FI, Giusti R, Fukuda K, Green DB, Castillo LC, et al. Evidence for sexual and mother-to-child transmission of human $\mathrm{T}$ lymphotropic virus type II among Guaymi Indians, Panama. J Infect Dis. 1995;171(4):1022-6.

31. Rabkin CS, Corbin DO, Felton S, Barker $\mathrm{H}$, Davison D, Dearden C, et al. Human Tcell lymphotropic virus type I infection in Barbados: results of a 20-year follow-up study. J Acquir Immune Defic Syndr Hum Retrovirol. 1996;12(5):519-22.

32. Silva Cabrera E, Perez Guevara MT, Lubian Caballero AL, de la Fuente Arzola JL, Navea Leyva L, Cruz Sui O. Pesquisaje de anticuerpos contra el virus linfotrópico de células T humanas tipo I (HTLV-I) en donantes de sangre y grupos de riesgo. Rev Cubana Med Trop. 1997;49(1):24-7.

33. Adedayo OA, Shehu SM. Human T-cell lymphotropic virus type 1 (HTLV-1) and lymphoid malignancies in Dominica: a seroprevalence study. Am J Hematol. 2004;77:336-9.

34. Rodriguez EM, de Moya EA, Guerrero E, Monterroso ER, Quinn TC, Puello E, et al. HIV-1 and HTLV-I in sexually transmitted disease clinics in the Dominican Republic. J Acquir Immune Defic Syndr. 1993;6(3):313-8.

35. Rouet F, Meertens L, Courouble G, Herrmann-Storck C, Pabingui R, Chancerel B, et al. Serological, epidemiological, and molecular differences between human T-cell lymphotropic virus Type 1 (HTLV-1)-seropositive healthy carriers and persons with HTLV-I Gag indeterminate Western blot patterns from the Caribbean. J Clin Microbiol. 2001;39(4): 1247-53.

36. Massari V, Elghouzzi MH, Agis F, Rannou C, Gordien E, Costagliola D, et al. Epidemiologic comparison of human Tlymphotropic virus type I-infected blood donors from endemic and nonendemic regions over a 3-year period. Transfusion. 1994;34(3):198-201.

37. Grant W, Bia FJ, Chacko TM, JeanBaptiste M, Griffith BP. Comparison of enzyme-linked immunosorbent and indirect immunofluorescence assays for the detection of human T-cell lymphotropic virus type-I antibodies in sera from rural Haiti. Diagn Microbiol Infect Dis. 1992; 15(2):121-4.

38. Murphy EL, Figueroa JP, Gibbs WN, Holding-Cobham M, Cranston B, Malley $\mathrm{K}$, et al. Human T-lymphotropic virus type I (HTLV-I) seroprevalence in Jamaica. I. Demographic determinants. Am J Epidemiol. 1991;133(11):1114-24.

39. Mansuy JM, Schlegel L, Villeneuve L, Mengelle C, Magnaval JF. Seroprevalence of retroviral infections among pregnant women in Martinique (French West Indies). Am J Trop Med Hyg. 1999;61:598-9.

40. Kaplan JE, Yamamura Y, Rios-Olivares EO, Cannon RO, Khabbaz RF, Gubler DJ, et al. Seroprevalence of human T lymphotropic virus type I in Puerto Rico. Am J Trop Med Hyg. 1989;40(6):659-62.

41. Daisley H, Charles W, Landeau P, Jackman L, Batson M, Gomez-Adams K. Screening for HTLV-1 in healthy blood donors in Trinidad and Tobago, West Indies. Trop Med Parasitol. 1991;42(4): 404-6.

42. Bartholomew C, Cleghorn F. Retroviruses in the Caribbean. Bull Pan Am Health Organ. 1989:23:76-80.

43. Manns A, Hisada M, LaGrenade L. Human T-lymphotropic virus type I. Lancet. 1999;353:1951-8.

44. Buggage RR. Ocular manifestations of human T-cell lymphotropic virus type 1 infection. Curr Opin Ophthalmol. 2003;14: 420-5.

45. LaGrenade L, Hanchard B, Fletcher V, Cranston B, Blattner W. Infective dermatitis of Jamaican children: a marker for HTLV-I infection. Lancet. 1990;336: 1345-6.

46. Hisada M, Stuver S, Okayama A, Li HC, Sawada T, Hanchard B, et al. Persistent paradox of natural history of human $\mathrm{T}$ lymphotropic virus type I: parallel analyses of Japanese and Jamaican carriers. J Infect Dis. 2004;190:1605-9.

47. Carneiro-Proietti AB, Catalan-Soares B, Proietti FA, GIPH (Interdisciplinary HTLV-I/IIResearch Group). Human $\mathrm{T}$ cell lymphotropic viruses (HTLV-I/II) in South America: should it be a public health concern? J Biomed Sci. 2002;9: 587-95.

48. Gotuzzo E, Arango C, de QueirozCampos A, Isturiz RE. Human T-cell lymphotropic virus-I in Latin America. Infect Dis Clin North Am. 2000;14(1):211-39.

49. Fujiyoshi $\mathrm{T}, \mathrm{Li} \mathrm{HC}$, Lou $\mathrm{H}$, Yashiki $\mathrm{S}$, Karino S, Zaninovic V, et al. Characteristic distribution of HTLV type I and HTLV type II carriers among native ethnic groups in South America. AIDS Res Hum Retroviruses. 1999;15(14):1235-9.

50. Dourado I, Alcantara LCJ, Barreto ML, Teixeira MG, Galvão-Castro B. HTLV-I in the general population of Salvador, Bra- zil: a city with African ethnic and sociodemographic characteristics. J Acquir Innune Defic Syndr. 2003;34:527-31.

51. Goubau P, Vandamme AM, Desmyter J. Questions on the evolution of primate Tlymphothropic viruses raised by molecular and epidemiological studies of divergent strains. J Acquir Immune Defic Syndr Hum Retrovirol. 1996;13:S24247.

52. Alcantara Jr LC, Van Dooren S, Goncalves MS, Kashima S, Costa MC, Santos FL, et al. Globin haplotypes of human T-cell lymphotropic virus type I-infected individuals in Salvador, Bahia, Brazil, suggest a post-Columbian African origin of this virus. J Acquir Immune Defic Syndr. 2003; 33(4):536-42.

53. Alcantara LCJ, Oliveira T, Gordon M, Marcarenhas RE, Cassol S, Galvão-Castro $B$. Investigating the origin of the Brazilian HTLV-1 using host virus genetic data. AIDS. (Forthcoming 2006).

54. Van Dooren S, Gotuzzo E, Salemi M, Watts D, Audenaert E, Duwe S, et al. Evidence for a post-Columbian introduction of human T-cell lymphotropic virus in Latin America. J Gen Virol. 1998;79:26952708.

55. Horai S, Kondo R, Nakagawa-Hattori $Y$, Hayashi S, Sonoda S, Tajima K. Peopling of the Americas, founded by four major lineages of mitochondrial DNA. Mol Biol Evol. 1993;10(1):23-47.

56. Vallinoto AC, Muto NA, Pontes GS, Machado LF, Azevedo VN, dos Santos SE et al. Serological and molecular evidence of HTLV-I infection among Japanese immigrants living in the Amazon region of Brazil. Jpn J Infect Dis. 2004;57(4):156-9.

57. Van Dooren S, Pybus OG, Salemi M, Liu HF, Goubau P, Remondegui C, et al. The low evolutionary rate of human T-cell lymphotropic virus type- 1 confirmed by analysis of vertical transmission chains. Mol Biol Evol. 2004;21(3):603-11.

58. Vandamme AM, Salemi M, Van Brussel M, Liu HF, Van Laethem K, Van Ranst $\mathrm{M}$, et al. African origin of human $\mathrm{T}$ lymphotropic virus type 2 (HTLV-2) supported by a potential new HTLV-2d subtype in Congolese Bambuti Efe Pygmies. J Virol. 1998;72:4327-40.

59. Alcantara LC, Shindo N, Van Dooren S, Salemi M, Costa MC, Kashima S, et al. Brazilian HTLV type 2a strains from intravenous drug users (IDUs) appear to have originated from two sources: Brazilian Amerindians and European/North American IDUs. AIDS Res Hum Retroviruses. 2003;19(6):519-23.

60. Switzer WM, Pieniazek D, Swanson $P$, Samdal HH, Soriano V, Khabbaz RF, et al. Phylogenetic relationship and geographic distribution of multiple human T-cell lymphotropic virus type II subtypes. J Virol. 1995;69(2):621-32.

61. Liu H, Leung P, Glynn S, Murphy EL. Human T-lymphotropic virus type II RFLP subtypes $\mathrm{a} 0$ and $\mathrm{b} 4 / \mathrm{b} 5$ are associated with different demographic and geographic characteristics in the United States. Virology. 2001;279(1):90-6. 
62. Shindo N, Alcantara LC, Van Dooren S, Salemi M, Costa MC, Kashima S, et al. Human retroviruses (HIV and HTLV) in Brazilian Indians: seroepidemiological study and molecular epidemiology of HTLV type 2 isolates. AIDS Res Hum Retroviruses. 2002;18(1):71-7.

63. Vallinoto $A C$, Ishak MO, Azevedo VN, Vicente AC, Otsuki K, Hall WW, et al. Molecular epidemiology of human Tlymphotropic virus type II infection in Amerindian and urban populations of the Amazon region of Brazil. Hum Biol. 2002; 74(5):633-44

64. Peters AA, Coulthart MB, Oger JJF, Waters DJ, Crandall KA, Baumgartner AA, et al. HTLV type I/II in British Columbia Amerindians: a seroprevalence study and sequence characterization of an HTLV type IIa isolate. AIDS Res Hum Retroviruses. 2000;16(9):883-92.
65. Sabino EC, Zrein M, Taborda CP, Otani MM, Ribeiro-Dos-Santos G, Saez-Alquezar A. Evaluation of the INNO-LIA HTLV I/II assay for confirmation of human Tcell leukemia virus-reactive sera in blood bank donations. J Clin Microbiol. 1999;37: 1324-8.

66. Salles NA, Sabino EC, Barreto CC, Barreto AM, Otani MM, Chamone DF. Descarte de bolsas de sangue e prevalência de doenças infecciosas em doadores de sangue da Fundação Pró-Sangue/Hemocentro de São Paulo. Rev Panam Salud Publica. 2003;13(2-3):111-6.

67. Seed CR, Margaritis AR, Bolton WV, Kiely P, Parker S, Piscitelli L. Improved efficiency of national HIV, HCV, and HTLV antibody testing algorithms based on sequential screening immunoassays. Transfusion. 2003:43:226-34.
68. Orland JR, Wang B, Wright DJ, Nass CC Garratty G, Smith JW, et al. Increased mortality associated with HTLV-II infection in blood donors: a prospective cohort study. Retrovirology. 2004;1(1):4.

69. Hisada M, Maloney EM, Sawada T, Miley WJ, Palmer P, Hanchard B, et al. Virus markers associated with vertical transmission of human T-lymphotropic virus type I in Jamaica. Clin Infect Dis. 2002;34: 1551-7.

70. Hisada M, Chatterjee N, Kalaylioglu Z, Battjes RJ, Goedert JJ. Hepatitis C virus load and survival among infected drug users in the United States. Hepatology. 2005;42(6):1446-52.

Manuscript received 19 September 2005. Accepted for publication 11 October 2005.

RESUMEN La primera descripción del virus de la leucemia humana de células T tipo 1 (VLHT-1) se hizo en 1980, y al poco tiempo, en 1982, se descubrió el VLHT-2. Desde entonces las características principales de estos virus, a los que a menudo se les llama VLHT-1/2, se han estudiado exhaustivamente. Centroamérica, América del Sur y el Caribe son áreas con una alta prevalencia de VLHT-1 y VLHT-2 donde hay conglomerados de personas infectadas. Las principales vías de transmisión han sido el contacto sexual, la sangre y sus derivados, y la de madre a hijo por la leche materna. El VLHT-1 se asocia con la leucemia o el linfoma de células T maduras (LTM), la mielopatía o paraparesia tropical espástica ligada al VLHT (M/PTE), y la uveítis ligada al VLHT, así como con la dermatitis infecciosa de la infancia. Se necesita más información acerca del posible papel que desempeña el VLHT en la aparición de enfermedades reumáticas, psiquiátricas e infecciosas. En vista de que no se dispone de ninguna cura para la LTM ni la M/PTE, como tampoco de ninguna vacuna para prevenir la transmisión del VLHT-1 y VLHT-2, estas enfermedades acarrean enormes costos sociales y económicos para las personas infectadas, sus parientes y los sistemas de salud. Por este motivo, las intervenciones sanitarias orientadas a asesorar e instruir a personas y poblaciones en alto riesgo revisten una importancia crítica. En el continente americano esto cobra aun más importancia en zonas de alta prevalencia.

Palabras clave Virus 1 linfotrópico T humano, virus 2 linfotrópico T humano, Retroviridae, donadores de sangre, medicina preventiva, Américas. 